\title{
Comparison of Time Management Perception of Students Studying at Department of Physical Education and Sports Teaching and Program in Primary School Education
}

\author{
Osman GUMUSGUL ${ }^{1}$ \\ Faculty of Sport Sciences, Suleyman Demirel University, Isparta, Turkey \\ Email:osmangumusgul@sdu.edu.tr Tel: +902462114759
}

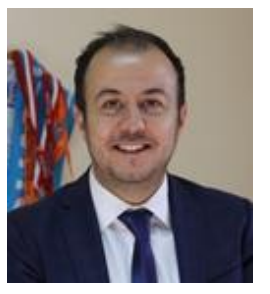

\begin{abstract}
The aim of this study was to compare time management perception of students studying at Department of Physical Education and Sports Teaching and program in Primary School Education. Totally, 170 students took part in this research. Data was gathered through Time Management Scale that had been developed by Britton and Tesser (1991) and was translated to Turkish Language by Alay and Koçak (2002). In evaluation part, frequency analysis and parametric tests were used. It was statistically determined that there were significant differences between students studying at department of physical education and sports teaching with program in primary school education. It is considered that the students of Physical Education and Sports Teaching Department have high perception in all three sub-dimensions because of their habit of using the time well in the competition or the habits of time planning such as nutrition and sleeping out of sporting time.
\end{abstract}

Keywords: Physical education and sports teaching, Primary school education, Time management

Citation | Osman GUMUSGUL (2018). Comparison of Time Management Perception of Students Studying at Department of Physical Education and Sports Teaching and Program in Primary School Education. Asian Journal of Education and Training, 4(3): 224-227.

History:

Received: 7 June 2018

Revised: 27 June 2018

Accepted: 29 June 2018

Published: 2 July 2018

Licensed: This work is licensed under a Creative Commons

Attribution 3.0 License $(\mathrm{cc}) \mathbf{E Y}$

Publisher:Asian Online Journal Publishing Group
Funding: This study received no specific financial support.

Competing Interests: The author declares that there are no conflicts of interests regarding the publication of this paper.

Transparency: The author confirms that the manuscript is an honest, accurate, and transparent account of the study was reported; that no vital features of the study have been omitted; and that any discrepancies from the features of the study have been omit
study as planned have been explained.

Ethical: This study follows all ethical practices during writing.

\section{Contents}

1. Introduction

2. Method

References. 


\section{Introduction}

Educators gain many behaviors towards their students as well as acquire skills in terms of managing time. The most important aspect of time management or using time effectively in the field of education is to provide planning skill. It is very important to be aware that it is not possible to compensate for the time left. To be planned means to make the right decisions for students and being tidy.

Today, the teacher has come out of being a passive individual who only teaches, distributes information and evaluates. In addition to being a teacher who teaches modern education understanding, who is the person who can hear, think, research, synthesize and analyze in order to be successful in future generations, it must be effective and efficient (Çăglayan, 2005). For this reason, teachers should be a good guide for the class in terms of time management. An activity that takes ten minutes in a class can go on longer or shorter than another class. For this reason, the teacher must know the circumstances in which the time-consuming user is going to act and create stimulus situations and environments accordingly (Özçelik, 2006; Gozel, 2009).

Time is a limited resource and like many other limited resources, time can be more or less effectively managed (Ustun et al., 2017). The concept of time, which is effective at every stage of life, is beginning to affect education profoundly. This is rather difficult for teachers who have just begun to attend. Determining the number of hours required for the course will prevent the course from being dispersed and away from the objective. For this reason, the teacher should give the necessary attention to the plan in order to help it Özçelik (2006).

As a problem nowadays, it is the widespread tendency of young people to direct a large part of their lives to activities that provide little or no personal development. The main purpose of this type of youth is to amuse themselves; (usually in the school or business environment) without being dependent on ignorance (Stebbins, 2016). In the century we live in, we can observe that with the rapid increase in scientific and technological innovations, daily conveniences have increased and personal working hours have decreased, which, in turn, has resulted in people having more spare time. In daily life, the boredom and repetitive features of our work and other activities have made leisure activities a critical tool of renewal in our lives (Demirel et al., 2017). The recreation activities which people do in their spare times have become essential components of community life (Demirel et al., 2017).

In communities, there is a need for a collective sense of time that individuals acquire in order to be able to conduct their affairs effectively; because people organize their daily lives depending on time (Safran and Şimşek, 2009; Üstün et al., 2016; Dall and Pekel, 2017). Many studies in different disciplines indicate that individuals should participate regularly in physical activity in their leisure time for a quality life (Demirel and Harmandar, 2009).

Very different definitions can be made for the management of the concept of relative perceived time for humans. Everyone tends to interpret the values that the context expresses for itself. It is not the attempt to explain the concept of time, but the planning of what can be done in the present time (Erdem and Kaya, 1998; Gümüşgül, 2013). Time management means planning time, purposes, responsibilities, pleasures and social activities together (Özgen, 2002).

For teachers, what they want to do in an academic year is important. In education, the importance of time management emerges here. For this reason, teachers, students, are always in a great effort. Therefore, the more effective the teachers use their time, the more successful the plans will be and the more successful their students will be in addition to their own success. To summarize, in terms of determining the works in the plans, determining the time period in which these works will be done, what kind of tools and tools will be used in the works, determining the works to be performed according to the order of operations, and checking whether all these processes do not reach the level management has a very important place in all educational institutions (Özçelik, $2006)$.

In this case, the aim of this study was to compare time management perception on different variables of students studying at Department of Physical Education and Sports Teaching with program in Primary School Education.

\section{Method}

170 students 88 studying at department of Physical Education and Sports Teaching; 82 studying at program in Primary School Education took part in this research.

In Britton and Glynn's time management experience and theoretical modeling, it is important to note that the steps of effective time management are to choose the main and sub-objectives, to identify the priorities and positions of these goals, to identify the priorities for the achievement of the main and sub- to take out the list of works and prepare time rulings for them and to do these works after all (Gumusgul, 2018). Based on this model, Time Management Scale, prepared by Britton and Tesser (1991) was aimed to measure the time management skills of university students. Time Management Scale adapted and translated to Turkish Language by Alay and Koçak (2002). Time Management Scale is a measure prepared using Likert Method. The answers consist of "always", "frequently", "sometimes", "infrequently" and "never".

The students who participated to the study were informed about the aim and content of the scale by the researcher before the lessons by taking the permission from the instructors and they were asked to leave a single marking and not to leave the questions as blank as possible.

The data obtained from the participants were evaluated in SPSS 20.0 statistical package program. The Kolmogorov Smirnov normality test was used to determine which statistical analysis available for the questionnaires returned from the participants and it was seen that the variables had normal distribution. For this reason, it was decided to apply parametric test such as Independent Sample T-test and One Way Anova tests in analysis of the variables. 


\section{Findings}

Table-1. Time management scores according to gender

\begin{tabular}{|c|c|c|c|c|c|c|}
\hline Subscales & Gender & $\mathbf{N}$ & Mean & Std. Deviation & $\mathrm{t}$ & $p$ \\
\hline \multirow{2}{*}{ Time Planning } & Male & 100 & 46,910 & 11,874 & \multirow{2}{*}{0,500} & \multirow{2}{*}{0,617} \\
\hline & Female & 70 & 46,086 & 9,549 & & \\
\hline \multirow{2}{*}{ Time Attitudes } & Male & 100 & 18,840 & 3,311 & \multirow{2}{*}{0,318} & \multirow{2}{*}{0,751} \\
\hline & Female & 70 & 18,671 & 3,467 & & \\
\hline \multirow{2}{*}{ Time Wasters } & Male & 100 & 11,470 & 2,897 & \multirow{2}{*}{3,717} & \multirow{2}{*}{0,000} \\
\hline & Female & 70 & 9,900 & 2,572 & & \\
\hline
\end{tabular}

According to Table 1, statistically significant difference was determined in time wasters subscale according to gender variable $(\mathrm{p}<0,05)$; on the contrary, there was no significant difference between time planning and time attitudes subscale and gender $(\mathrm{p}>0,05)$.

Table-2. Time management scores according to department

\begin{tabular}{|c|c|c|c|c|c|c|}
\hline Subscales & Department & $\mathbf{N}$ & Mean & Std. D. & $\mathrm{t}$ & $\mathbf{p}$ \\
\hline \multirow{2}{*}{ Time Planning } & Physical Ed. and Sports Teaching & 88 & 49.523 & 11.154 & \multirow{2}{*}{3.797} & \multirow{2}{*}{0.000} \\
\hline & Primary School Education & 82 & 43.402 & 9.853 & & \\
\hline \multirow{2}{*}{ Time Attitudes } & Physical Ed. and Sports Teaching & 88 & 19.432 & 3.265 & \multirow{2}{*}{2.699} & \multirow{2}{*}{0.008} \\
\hline & Primary School Education & 82 & 18.061 & 3.349 & & \\
\hline \multirow{2}{*}{ Time Wasters } & Physical Ed. and Sports Teaching & 88 & 11.000 & 2.936 & \multirow{2}{*}{0.832} & \multirow{2}{*}{0.406} \\
\hline & Primary School Education & 82 & 10.634 & 2.796 & & \\
\hline
\end{tabular}

According to the results in Table 2, there was significant difference between time management perception levels of students studying Department of Physical Education and Sports Teaching and program in Primary School Education $(\mathrm{p}<0,05)$.

Table-3. Time management scores according to academic score

\begin{tabular}{|c|c|c|c|c|c|c|c|}
\hline Subscales & Academic Score (on 4,00$)$ & $\mathbf{N}$ & Mean & $\mathbf{S}$ & $\mathbf{F}$ & $\mathbf{P}$ & Tukey \\
\hline \multirow{5}{*}{ Time Planning } & 2,00 and less & 16 & 46,6875 & 11,88118 & \multirow[b]{3}{*}{4.099} & \multirow[b]{3}{*}{0.008} & \multirow{3}{*}{$\begin{array}{l}2-3^{*} \\
2-4^{*}\end{array}$} \\
\hline & $2,01-2,50$ & 46 & 51,1739 & 9,79638 & & & \\
\hline & $2,51-3,00$ & 67 & 44,6716 & 11,91941 & & & \\
\hline & $3,01-4,00$ & 41 & 44,4634 & 8,75528 & \multirow[b]{5}{*}{0.357} & \multirow[b]{5}{*}{0.784} & \\
\hline & Total & 170 & 46,5706 & 10,95382 & & & \\
\hline \multirow{5}{*}{ Time Attitudes } & 2,00 and less & 16 & 18,375 & 3,42296 & & & \\
\hline & $2,01-2,50$ & 46 & 18,5435 & 3,13905 & & & \\
\hline & $2,51-3,00$ & 67 & 18,7612 & 3,52519 & & & \\
\hline & $3,01-4,00$ & 41 & 19,1951 & 3,40749 & \multirow{7}{*}{1.682} & \multirow{7}{*}{0.173} & \\
\hline & Total & 170 & 18,7706 & 3,36713 & & & \\
\hline \multirow{5}{*}{ Time Wasters } & 2,00 and less & 16 & 11,1875 & 2,31571 & & & \\
\hline & $2,01-2,50$ & 46 & 11,5435 & 2,95677 & & & \\
\hline & $2,51-3,00$ & 67 & 10,5373 & 2,94561 & & & \\
\hline & $3,01-4,00$ & 41 & 10,3415 & 2,74417 & & & \\
\hline & Total & 170 & 10,8235 & 2,86656 & & & \\
\hline
\end{tabular}

According to Anova results in Table 3 which were applied to determine whether there were significant differences between time management skills and academic score. It was determined that there were significant differences between time planning subscale and academic score $(p<0,05)$. According to the Tukey test to determine which variable cause significant difference, significance was found to be in the range of 2.01-2.50 grades (Mean= $51,17)$.

\section{Conclusion}

Physical Education and Sports Teaching students, in other words, physical education and sports teacher candidates have been observed as having more time management skills than Primary School Education Students. It can be thought that this is due to Physical Education and Sports Teaching Students' habits of using time well in the competitions or the habits of time planning such as nutrition and sleeping out of sporting time. It is also thought that Physical Education and Sports Teaching students should train based on daily, weekly and yearly training programs they continue to work within. Moreover, while Demirtas and Özer (2007) found statistically significant difference between time management skills and department; Andıç (2009) did not find any significant difference according to department variable.

Independent sample t-test was used to determine whether there was meaningful difference between time management understandings of students participating in the study and their genders. The results of the analysis show that there has been statistically significant difference between the students' time management understanding and gender. It is considered that the reason for the significant difference in time wasters subscale may be that male participants have more time-consuming activity diversity than women because of the Turkish society structure. Throughout the day, male participants can spend more time on their private affairs and getting different habits that can provide benefits makes them more time-consuming. Therefore, it can be thought that this situation has been caused by the fact that the male students can leave important works for the last minute comparing to female students. It has been also thought that one of the reasons of this difference is that male and female students perceive time differently and perceive it with different attitudes and plans. Supporting this research, Alay (2000); 
Demirtas and Özer (2007); Eldeleklioğlu (2008) found that there was statistically significant difference between gender and students' opinions about subscale of time wasters.

One way Anova was applied to determine whether there was a meaningful difference between participants' time management understanding and general academic grade averages. According to the analysis, it was determined that there is a meaningful difference between time planning subscale and general academic grade averages. It is thought that the result that the candidates with a general academic grade average between 2.01 and 2.50 better managing time, because sample group of the study had better planning in short and long term comparing to the students with the other grades.

In consideration of all these results, to make certain time management for students as both student and teacher candidate should be thought as essential issue. With the 'more effective the teachers use their time, the more successful the plans will be and the more successful their students will be in addition to their own success' principle, physical activity and sports should be seen an important variable for time management and not only physical education and sports teaching but also other field teacher candidates should be inclined to physical education and sports lectures on their schedule. However, in line with the principle of equality, local and central authorities should create more free time activities for women and should increase their education in public education centers as well as in schools.

\section{References}

Alay, S., 2000. Relationship between time management and academic achivement of selected university students. Master Thesis. Middle East Technical University, Ankara.

Alay, S. and S. Koçak, 2002. Validity and reliability of time management questionnaire. Hacettepe University Journal of Education, 22(22): 913. View at Google Scholar

Andıç, H., 2009. The relation between academic successes and time management of university students (Afyonkarahisar Case). Master Thesis, Afyonkocatepe University, Afyonkarahisar.

Britton, B.K. and A. Tesser, 1991. Effects of time-management practices on college grades. Journal of Educational Psychology, 83(3): 405410. View at Google Scholar | View at Publisher

Çăglayan, A., 2005. Education in primary education, quality in management. İstanbul: Bilge Publishing.

Dall, M. and A. Pekel, 2017. Examination of future time perception levels and time management behaviours of the students in the faculties of sports sciences by certain variables. Journal of Human Sciences, 14(2): 1420-1434. View at Google Scholar $\mid$ View at Publisher

Demirel, D.H., M. Demirel and E. Serdar, 2017. University students' opinions of the meaning of leisure and their perceived freedom in leisure. International Journal of Human Sciences, 14(1): 796-802. View at Google Scholar | View at Publisher

Demirel, M., D.H. Demirel and E. Serdar, 2017. Constraints and perceived freedom levels in the Leisure of University students. International Journal of Human Sciences, 14(1): 789-795. View at Google Scholar $\mid$ View at Publisher

Demirel, M. and D. Harmandar, 2009. Determination of the constraints on recreational participation of university students. International Journal of Human Sciences, 6(1): 838-846. View at Google Scholar

Demirtas, H. and N. Ve Özer, 2007. The relationship between teacher candidates' time management skills and academic success. Educational Policy Analysis and Strategic Research, 2(1): 34-48.

Eldeleklioğlu, J., 2008. Investigation of adolescents' time management skills in terms of anxiety, age and gender variables. Elementary Education Online, 7(3): 656-663. View at Google Scholar

Erdem, R. and S. Kaya, 1998. Time management. Modern Local Governments, 7(2): 99-120.

Gozel, E., 2009. The views of elementary and middle school teachers about the time management. Master Thesis, Afyon Kocatepe Üniversitesi, Afyon.

Gumusgul, O., 2018. Time management: Within the scope of free time evaluation. Beau Bassin: LAP Lambert Academic Publishing.

Gümüşgül, O., 2013. The research of time management understanding for the students studying in European Union countries and Turkey in Terms of Different Variables. Master Thesis, Dumlupınar University, Kutahya.

Özçelik, G., 2006. Effective Time management in institutions that apply fashion education. Master Thesis, Gazi University, Ankara.

Özgen, C., 2002. Efficient time management. Ankara: Bilkent University Publishing.

Safran, M. and A. Şimşek, 2009. Development of time perception in children. Journal of International Social Research, 2(6): $542-548$.

Stebbins, R.A., 2016. The Idea of leisure first principles (M. Demirel, NE Ekinci, ÜD Üstün, U. Işık, O. Gümüşgül Trans.), Ankara: Sports Publishing.

Ustun, U.D., A. Ersoy and A. Berk, 2017. An investigation on time management and communication skills of physical education and sport students. Sp. Soc. Int. J. Ph. Ed. Special Issue: 20-24.

Üstün, Ü.D., O. Gümüşgül, U. Işılk, M. Demirel and D.H. Demirel, 2016. Future time perception: A study on school of physical education and sports students. Istanbul University Journal of Sport Science, 6(1): 10-20. 